УДК 347.771

DOI https://doi.org/10.32837/pyuv.v0i4.620

\author{
P. О. Юрків \\ orcid.org/0000-0003-3177-1265 \\ аспірант кафедри інтелектуальної власності, \\ інформаційного та корпоративного права \\ Львівського національного університету імені Івана Франка
}

\title{
УМОВИ ВИДАЧІ ПРИМУСОВИХ ЛІЦЕНЗІЙ НА ВИНАХОДИ (КОРИСНІ МОДЕЛІ)
}

Постановка проблеми. Примусове ліцензування у сфері інтелектуальної власності є інструментом збалансування приватних i публічних інтересів у разі використання майнових прав на конкретно визначені об'єкти. Можливість застосування процедури примусового ліцензування встановлена міжнародно-правовими документами - Паризькою конвенцією про охорону промислової власності, Угодою про торговельні аспекти прав інтелектуальної власності. Відповідні приписи закріплені й у національному законодавстві.

У сфері правового регулювання примусового ліцензування накопичилося чимало проблем, пов'язаних із неповнотою, непослідовністю, суперечливістю правових підходів, що утруднюе практику їх застосування. Актуальною є проблема гармонізації законодавства України з правом Європейського Союзу (далі - ЄС), його відповідність кращим світовим стандартам. Усе наведене зумовлює актуальність вибору теми наукового дослідження.

Стан дослідження. Проблеми правового регулювання примусового ліцензування, практики застосування відповідного законодавства в науковій літературі досліджувалися переважно в контексті більш загальних питань права інтелектуальної власності на окремі об'єкти, правових підстав розпорядження відповідними майновими правами тощо. У цьому аспекті варто зазначити про дисертаційні дослідження Є.Ш. Гареєва «Правова охорона винаходів» $(2007$ р.) [2]. Окремі аспекти примусового ліцензування досліджувалися на рівні наукових публікацій такими науковцями, як Г.О. Андрощук [3], Л.І. Работягова [4], О.Ю. Кашинцева [5], 0.О. Пономарьова [6] та іншими. Однак вказані наукові дослідження не охоплювали належним чином аналіз проблематики примусового ліцензування, а стосувалися окремих аспектів патентного права, в тому числі й щодо загальних засад видачі примусових ліцензій.

Цілями статті є характеристика національного законодавства щодо умов примусового ліцензування винаходів, корисних моделей, обгрунтування висновків стосовно вдосконалення правового регулювання досліджуваних відносин.

Завданням статті є схарактеризувати примусову ліцензію на винахід (корисну модель), дослідити поняття «невикористання та недостатне використання винаходу (корисної моделі)», проаналізувати судовий порядок видачі примусової ліцензії.

Основний матеріал. Примусова ліцензія на винахід (корисну модель) - особлива, виняткова правова підстава використання майнових прав інтелектуальної власності власника патенту на винахід (корисну модель).

У ст. 24 Закону України «Про охорону прав на винаходи і корисні моделі" в першій редакції від 15 грудня 1993 р. зазначалося: виходячи із суспільних інтересів та інтересів національної безпеки, Кабінет Міністрів України має право дозволити використання винаходу (корисної моделі) без згоди власника патенту, але з виплатою йому відповідної компенсації. Спори щодо умов видачі дозволу й виплати компенсації та іiї розміру розв'язуються в судовому порядку [7]. Очевидно, що така редакція зазначеної статті була невдалою. Насамперед самі поняття «суспільний інтерес» та «інтереси національної безпеки» досить розпливчасті, неконкретизовані. За таких підходів могли допускатися зловживання в разі видачі ліцензії проти волі власника патенту. Та й саме надання такого права виключно Кабінетом Міністрів України як органу виконавчої влади викликало сумніви й суперечило міжнародній практиці.

У редакції Закону України «Про охорону прав на винаходи і корисні моделі» від 1 червня 2000 р. з'явилася окрема ст. 30 - Примусове відчуження прав на винахід (корисну модель). Ї̈ї норми деталізували умови, порядок і наслідки видачі примусових ліцензій на винаходи й корисні моделі. Норми цієї статті редакційно змінені Законом від 22 травня $2003 \mathrm{p}$.

Насамперед варто зауважити про назву цієї статті. Адже сама видача будь-якої ліцензії (в тому числі й примусової) не свідчить про відчуження прав інтелектуальної власності. Таке відчуження проходить на підставі договору про передання виключних майнових прав інтелектуальної власності - п. 4 ст. 1107 Цивільного кодексу України (далі - ЦК України).

Як випливає з норми ч. 1 ст. 1108 ЦК України, ліцензія - це дозвіл особи, що має виключне право дозволяти використання об'єкта права інтелектуальної власності (ліцензіара), іншій особі (лі- 
цензіату). Такий дозвіл надає ліцензіату право на використання цього об'єкта в певній обмеженій сфері. Відчуження прав не проходить. Призначення ліцензії - бути правовою підставою використання на певних умовах залежно від виду ліцензії, майнових прав інтелектуальної власності. Таке використання є завжди платним, строковим і жодним чином не свідчить про перехід прав від власника патенту до іншої особи, якій видано ліцензію. Та обставина, що ліцензія видається проти волі власника, не змінює ії сутності саме як підстави використання відповідних прав. Тому назву ст. 30 Закону «Про охорону прав на винаходи і корисні моделі» доречно змінити.

Відповідно до ч. 1 ст. 30 Закону «Про охорону прав на винаходи і корисні моделі», якщо винахід (корисна модель), крім секретного винаходу (корисної моделі), не використовується або не достатньо використовується в Україні протягом трьох років, починаючи від дати публікації відомостей про видачу патенту або від дати, коли використання винаходу (корисної моделі) було припинено, то будь-яка особа, яка має бажання та виявляє готовність використовувати винахід (корисну модель), у разі відмови власника прав від укладання ліцензійного договору може звернутися до суду із заявою про надання їй дозволу на використання винаходу (корисної моделі).

Таким чином, можемо виокремити такі умови видачі примусової ліцензії:

1) невикористання або недостатнє використання винаходу (корисної моделі) без поважних причин в Україні протягом 3-х років;

2) відмова власника прав від укладення ліцензійного договору з потенційним користувачем;

3) бажання та готовність особи, що бажає отримати ліцензію, використовувати винахід (корисну модель).

Зазначені умови мають використовуватися в сукупності.

Отже, насамперед має бути встановленим факт невикористання або недостатнього використання винаходу (корисної моделі) в Україні впродовж 3-х років, починаючи від дати публікації відомостей про видачу патенту або від дати, коли використання винаходу (корисної моделі) було припинено. Таким чином, трирічний строк невикористання (недостатнього використання) повинен бути безперервним, він не прив'язується до дати видачі патенту.

Поняття «невикористання», «недостатне використання» оцінне. Оскільки до суду позивається зацікавлена у використанні винаходу (корисної моделі) особа, то саме вона й має доводити такі обставини. Варто зауважити, що вищі судові інстанції натепер не дають навіть орієнтовних підходів, критеріїв щодо тлумачення як цих понять, так і допустимих, належних засобів їх доказування.
Постанова Пленуму Вищого господарського суду України від 17 жовтня 2012 р. «Про деякі питання практики вирішення спорів, пов'язаних із захистом прав інтелектуальної власності» 10 липня 2014 р. була доповнена п. 831 щодо залежних ліцензій [8]. Жодних інших роз'яснень, рекомендацій щодо застосування норм ст. 30 Закону «Про охорону прав на винаходи і корисні моделі» й аналогічних норм інших законів, що встановлюють примусове ліцензування, не надавалося.

Варто звернути увагу на важливий принцип, сформульований у п. 831 вказаної постанови: базовим принципом, що забезпечує патентування винаходів, є те, що будь-яка особа, яка використовує запатентований винахід без дозволу власника патенту, здійснює протиправні дії (за виключенням випадків, прямо передбачених чинним законодавством) [8].

Дозвіл власника патенту визначальний. Тільки 3 його дозволу на договірних засадах може здійснюватися правомірне використання майнових прав інтелектуальної власності. Але за певних, чітко визначених законом умов власник патенту (свідоцтва) може бути зобов'язаний до видачі ліцензії. Такий підхід відповідає світовій практиці й має відповідне нормативне закріплення.

Очевидно, тлумачення «невикористання», «недостатнє використання» надається судом, що розглядає справу, з урахуванням конкретних обставин. Оскільки використання винаходів (корисних моделей), майнових прав на них можливе лише зі згоди власника патенту й на підставі ліцензійних договорів чи виданих ліцензій, то їх відсутність i буде свідчити про факт невикористання.

Невикористання винаходу (корисної моделі) означає відсутність будь-яких дій щодо здійснення прав інтелектуальної власності власником патенту або особою, якій було передано права в порядку правонаступництва, наприклад, за договором чи в порядку спадкування.

Оцінити недостатне використання складніше. Варто брати до уваги можливий економічний ефект від використання на підставі одиничних ліцензій і прогнозовані втрати через те, що власник патенту відмовляється від видачі більшої кількості ліцензій чи від укладення більшої кількості ліцензійних договорів. Але тут варто враховувати й інтереси власника патенту. Адже економічний ефект від монопольного володіння одиничною чи виключною ліцензією може бути більшим, ніж використання майнових прав на підставі невиключних ліцензій. Тому, розглядаючи відповідні спори, суд має оцінити всі обставини в їх сукупності.

Тлумачення поняття «недостатне використання прав на винахід (корисну модель)» слід здійснювати з урахуванням таких засад цивільного законодавства, як розумність, добросовісність i справедливість. Недостатне використання відбу- 
вається тоді, коли власник прав на винахід (корисну модель) здійснює певне незначне використання винаходу (корисної моделі), що характеризується як обсягом промислового використання (майже не використовується у виробничому процесі патентовласника або інших осіб), так і часом такого використання (нетривалий проміжок). Хоча відсутність законодавчих положень щодо конкретизації ознак недостатнього використання винаходу (корисної моделі) може зумовлювати неоднозначне застосування цієї норми закону.

Причому до уваги береться факт невикористання чи недостатнього використання саме в Україні. Якщо винахід (корисна модель) використовуються за кордоном, то ця обставина не має значення.

У ч. 1 ст. 30 Закону також встановлено, що, якщо власник патенту не доведе, що факт невикористання винаходу (корисної моделі) зумовлений поважними причинами, суд виносить рішення про надання дозволу зацікавленій особі на таке використання. Знову ж таки відсутні будь-які роз'яснення щодо оцінки поняття «поважні причини». Розглядаючи відповідні спори, суд виходить із конкретних обстави справи. Доведення поважності причин покладається на власника патенту, що цілком вірно. Не зацікавлена у використанні винаходу (корисної моделі) особа доводить неповажність причин невикористання, недостатнього використання, а саме власнику патенту надається відповідна можливість пояснити суду причини невикористання винаходу (корисної моделі). Наприклад, такими поважними причинами невикористання, недостатнього використання можуть бути модернізація чи інша реконструкція виробництва, вплив непереборної сили на виробничий процес, мораторій на виконання зобов'язань, введення умов карантину тощо.

Щодо відмови власника прав від укладення ліцензійного договору, варто зауважити таке. Зацікавлена особа може позиватися до суду про видачу їй примусової ліцензії, якщо власник патенту відмовляється від укладення ліцензійного договору. Звертаємо увагу, що будь-яка особа, спираючись на принцип свободи договору, вільна в його укладенні, виборі контрагента, формуванні змісту, за винятком імперативного правового регулювання. На цю обставину звернуто увагу й в літератуpi. Власник патенту вільний у виборі ліцензіата й може видавати ліцензію будь-кому чи не видавати їі взагалі, укладати ліцензійний договір чи не укладати [9, с. 418].

Очевидно, має йтися про відмову в укладенні договору із зацікавленою особою в сукупності з фактами невикористання без поважних причин винаходу (корисної моделі). Зацікавлена сторона має навести докази відмови в укладенні договору 3 нею. Причому має йтися не тільки про відмову в укладенні договору (очевидно, що це ліцензій- ний договір), а й про відмову у видачі ліцензії. Тому для усунення непорозумінь у буквальному тлумаченні норм ст. 30 Закону «Про охорону прав на винаходи і корисні моделі» варто уточнити в їі ч. 1 після слів «у разі відмови власника патенту (а не прав) від укладання ліцензійного договору»словами «чи видачі ліцензії». Ліцензійний договір і ліцензія - окремі самостійні підстави використання майнових прав інтелектуальної власності.

Як випливає зі змісту ст. 30 Закону, зацікавлена у використанні винаходу (корисної моделі) особа має як мати бажання, так і виявляти готовність до використання. Оскільки особа позивається до суду, то в такий спосіб вона вже виявляє бажання використовувати винахід (корисну модель). Перевірка для суду готовності до використання може стати й проблематичною, адже потрібні відповідні фінансові-економічні, господарські показники, бізнес-плани тощо, що свідчать про готовність. Разом із тим із метою захисту прав власника патенту буде не зайвим судове встановлення факту готовності до використання як фінансової запоруки майбутніх ліцензійних платежів на користь власника патенту.

Отже, з дотриманням зазначених умов та їх доведеністю суд може постановити рішення про надання дозволу зацікавленій особі на використання винаходу (корисної моделі) з визначенням обсягу його використання, строку дії дозволу, розміру й порядку виплати винагороди власнику патенту. Водночас право власника патенту надавати дозволи на використання винаходу (корисної моделі) не обмежується. Йдеться про невиключний характер примусової ліцензії. Видавши ліцензію на підставі рішення суду, власник патенту не позбавляється права видавати ліцензії на використання винаходу (корисної моделі) будь-яким іншим особам на його розсуд і взаємовигідних умовах.

Строки використання, розмір і способи виплати винагороди власнику патенту визначаються судовим рішенням. На підставі судового рішення видається невиключна ліцензія, в якій і фіксуються відповідні умови. Не виключено, що сторони можуть укласти ліцензійний договір, на підставі якого може бути видана ліцензія. Особливістю такого ліцензійного договору буде те, що його умови закріплені рішенням суду.

Варто акцентувати увагу на тій обставині, що рішення суду не підміняє видачі ліцензії. Її видає сам власник патенту, але умови ліцензії визначені рішенням суду.

Відзначаємо, що з позицій власника патенту видача примусової ліцензії - це спеціальний обов'язок, що здійснюється за наявності законодавчо встановлених умов виключно в судовому порядку чи за рішенням Кабінету Міністрів України. Сама ж видача ліцензії є одностороннім правочином, передумовою вчинення якого є від- 
повідне рішення суду. Проте до такого правочину не можуть бути застосовані норми ЦК України про правочини, зокрема в частині визнання правочину недійсним і застосування відповідних правових наслідків. Замість волі й волевиявлення власника патенту правове значення для вчинення такого правочину має рішення суду. Якщо власник патенту діяв під впливом насильства, погрози, обману чи інших обставин, що за звичайних умов мають значення для правомірності вчиненого правочину, то оцінка таким обставинам має бути надана в рішенні суду. Власник патенту може оскаржити рішення суду у встановленому порядку. Позиватися про визнання ліцензії недійсною можливо, якщо з'явилися нові обставини, які не були відомі на момент постановлення рішення, але якби були відомі, то могли б вплинути на прийняття як самого рішення, так і окремих умов ліцензії, що були затверджені судовим рішенням.

Висновки. Встановлено, що умовами видачі примусової ліцензії на винахід (корисну модель) є невикористання або недостатне використання винаходу (корисної моделі) без поважних причин в Україні протягом 3-х років, небажання власника патенту укласти ліцензійний договір із потенційним користувачем і бажання та готовність особи, що бажає отримати ліцензію, використовувати винахід (корисну модель). Доведено, що правовою підставою користування майновими правами інтелектуальної власності на підставі примусової ліцензії є юридичний склад: рішення суду, що набрало законної сили, про видачу примусової ліцензії; видача невиключної ліцензії. Обгрунтовано, що саме рішенням суду визначається розмір і порядок виплати ліцензійних платежів, строк дії ліцензії та інші умови використання. Визначено, що примусова ліцензія на винахід (корисну модель) є невиключною, зокрема, видавши таку ліцензію, власник патенту не позбавляється права видавати інші ліцензії зацікавленим користувачам без обмежень.

Подальші наукові дослідження повинні спрямовуватися на поглиблений аналіз умов видачі примусових ліцензій на винаходи й корисні моделі з урахуванням відповідного досвіду правового регулювання країн ЄС. Окрему увагу слід приділити дослідженню подальшого реформування законодавства про примусове ліцензування в контексті створення Національного офісу інтелектуальної власності.

\section{Jimepamypa}

1. Гареєв Є.Ш. Правова охорона винаходів : автореф. дис. ... канд. юрид. наук : 12.00 .03 ; Одес. нац. юрид. акад. Одеса, 2007. 20 с.

2. Ярошевська Т.В. Право на службовий винахід : автореф. дис. ... канд. юрид. наук : 12.00 .03 ; Київський національний ун-т ім. Тараса Шевченка. Киӥв, 2009. $19 \mathrm{c}$.
3. Андрощук Г.О., Работягова Л.І. Патентне право: міжнародно-правове регулювання. НДІ інтелектуальної власності НАПрН України. Київ : Інтерсервіс, 2015. $286 \mathrm{c}$.

4. Работягова Л.І. Патент на корисну модель: забезпечення балансу прав. Теорія і практика інтелектуальної власності. 2006. № 5. С. 26-34.

5. Кашинцева О.Ю. Примусове ліцензування лікарських засобів: досвід ЄС. Теорія і практика інтелектуальної власності. 2016. № 6. С. 5-9. URL: http://www.inprojournal.org/wp-content/uploads/ 2017/10/Kashyntseva-0._317.pdf.

6. Пономарьова О.О. Примусова, відкрита та добровільна ліцензії на лікарські засоби: деякі аспекти правозастосування. Теорія і практика інтелектуальної власності. 2019. № 3. С. 32-38.

7. Про охорону прав на винаходи і корисні моделі : Закон України від 15 грудня 1993 р. № 3687-XII / Bepховна Рада України. URL: https://zakon.rada.gov.ua/ laws/show/3687-12/ed20000711\#Text.

8. Про деякі питання практики вирішення спорів, пов'язаних із захистом прав інтелектуальної власності : Постанова Пленуму Вищого господарського суду України від 17 жовтня 2012 р. № 12 / Вищий господарський суд України. URL: https://zakon.rada.gov.ua/ laws/show/v0012600-12\#Text.

9. Інтелектуальне право України / за заг. ред.. проф. О.С. Яворської. Тернопіль : Підручники і посібники, 2016. 608 с.

\section{Анотація}

Юрків Р. О. Умови видачі примусових ліцензій на винаходи (корисні моделі). - Стаття.

У статті розглянуто підстави й порядок примусового ліцензування прав на винаходи й корисні моделі, схарактеризовано примусову ліцензію на винахід (корисну модель), досліджено поняття «невикористання та недостатне використання винаходу (корисної моделі)» як підстави видачі примусової ліцензії, проаналізовано судовий порядок видачі примусової ліцензії та визначено її умови.

Установлено, що умовами видачі примусової ліцензії на винахід (корисну модель) є невикористання або недостатне використання винаходу (корисної моделі) без поважних причин в Україні протягом 3-х років, небажання власника патенту укласти ліцензійний договір із потенційним користувачем i прагнення та готовність особи, що бажає отримати ліцензію, використовувати винахід (корисну модель). Доведено, що правовою підставою користування майновими правами інтелектуальної власності на підставі примусової ліцензії є юридичний склад: рішення суду, що набрало законної сили, про видачу примусової ліцензії; видача невиключної ліцензії. Доведено, що рішення суду не підміняє видачі примусової ліцензії, яку видає сам власник патенту. Обгрунтовано, що саме рішенням суду визначається розмір і порядок виплати ліцензійних платежів, строк дії ліцензії та інші умови використання.

Визначено, що примусова ліцензія на винахід (корисну модель) є невиключною, зокрема, видавши таку ліцензію, власник патенту не позбавляється права видавати інші ліцензії зацікавленим користувачам без обмежень.

Відзначено, що з позицій власника патенту видача примусової ліцензії - це спеціальний обов'язок, що здійснюється за наявності законодавчо встановлених умов виключно в судовому порядку чи за рішенням Кабінету Міністрів України. Сама ж видача ліцензії 
$€$ одностороннім правочином, передумовою вчинення якого є відповідне рішення суду.

Ключові слова: примусова ліцензія, винахід, корисна модель, патент, суд, права інтелектуальної власності.

\section{Summary}

Yurkiv R. O. Conditions for granting a compulsory license for inventions (utility models). - Article.

The article considers the grounds and procedure for compulsory licensing of rights to inventions and utility models, describes the compulsory license for inventions (utility models), explores the concept of "non-use and insufficient use of inventions (utility models)" as grounds for granting compulsory licenses, analyzes court procedures for granting the compulsory licenses, and its conditions are defined.

It is established that the conditions for granting a compulsory license for an invention (utility model) are non-use or insufficient use of the invention (utility model) without good reason in Ukraine for 3 years, reluctance of the patent owner to enter into a license agreement with a potential user, who wants to get a license and use the invention (utility model). It is proved that the legal basis for the use of intellectual property rights on the basis of a compulsory license is the legal structure: the court decision, which has entered into force, on the granting of a compulsory license; granting of a non-exclusive license. It is proved that the court decision does not replace the granting of a compulsory license issued by the patent owner. It is substantiated that the court decision determines the amount and procedure for payment of license fees, the term of the license and other conditions of use.

It is determined that a compulsory license for an invention (utility model) is non-exclusive, in particular, by granting such a license, the patent owner is not deprived of the right to grant other licenses to interested users without restrictions.

It is noted that from the standpoint of the patent owner, the granting of a compulsory license is a special obligation, which is carried out in the presence of legally established conditions only in court or by the decision of the Cabinet of Ministers of Ukraine. The granting of a license itself is a unilateral transaction, the precondition for which is a relevant court decision.

Key words: compulsory license, invention, utility model, patent, court, intellectual property rights. 